\title{
RESTAURANT FACILITIES: TERRITORIAL ORGANIZATION AND SIGNIFICANCE IN HUMAN GEOGRAPHY (EVIDENCE FROM KYIV REGION)
}

\begin{abstract}
This paper is intended to describe the most significant features of restaurant facilities industry and its territorial organization in Kyiv region.

Restaurant facilities can bee seen as a part of economics that develops rapidly during last decades, ensuring economic growth and providing workplaces. It is also a crucial part of the tourist infrastructure, public space and an interesting cultural phenomenon which broadens knowledge about food traditions around the world. Kyiv region is such a part of Ukraine where processes of the restaurant facilities development could be observed multilaterally through all types of restaurant enterprises - cafes, bars, catering, restaurants, street food points, delivery etc.

In the paper, the significance of restaurant facilities in the economy has been outlined. The analysis of statistic data and personal observations has been conducted to examin the condition of territorial organization of restaurant facilities of Kyiv city and adjoying territories. Correlation analysis of restaurant industry interconnections and cluster analysis for determination of regional differences has been implemented.

Presented research leads to the condition of restaurants facilities industry from the perspective of the Human Geography and demonstrates the latest trends in its development.

In addition, problems and ways of improving the restaurant industry in Kiev has been identified and finally some recommendations about proceeding research has been proposed.
\end{abstract}

Keywords Restaurant facilities, territorial organization, urban development, Kiev. 


\section{Introduction}

The restaurant business is a branch of the economy that assures the economic development of the territory, fulfills important social functions - employment of population, covers the needs of nutrition, and serves as a public space for communication and education. Investigation of spatial-territorial aspects of the restaurant business assumed special importance in the former Soviet space due to the transfer to market economy conditions. Territorial organization of restaurant facilities is a narrow branch of Human Geography, which is faintly represented in literature. Papers about restaurant facilities are mostly devoted to the:

- particular quantitate data about restaurant facilities: number of enterprises in different regions / countries (Otsuka 2015; National Restaurant Association 2016);

- economic sides of industry - marketing or business planning of restaurant enterprises (Marvin 1991; Kuznetsova 1997; Sloan, Leith 2004; Godsmark 2005);

- technology and standards, demands of food production in restaurant facilities (Usov 1990; Godsmark 2005), food consumption (Atkins, Bowler 2001);

- recommendations about location of new restaurants according to the construction, design and urban planning requirements (Lawson 1994; Alonzo 1995; Godsmark 2005; Walker 2008);

- history of restaurant facilities (Berezhnoi 1980; Pyatnytska 2007);

- restaurant facilities as a part of regional economy (Yurkivskyi 1989; Karsekin 1990; Dudnyk 2002).

Unexplored and less investigated aspects are:

- more various and integrated quantitative data about restaurant facilities;

- models describing differences in restaurant facilities inside one region (for example, Kyiv) considering the background of the territory;

- the interconnection between economics and territorial organization of restaurant facilities in the market economy conditions;

- the condition of territorial organization of restaurant facilities as a result of human, cultural and socio-economical behaviour.

This article is intended to determine the significance of restaurant business in the economy and its importance in the ground of Human Geography and to explain the factors of industry development and finally to research locational and territorial characteristics of the restaurant industry in the city (for example, for Kyiv region).

\section{Methodology}

Restaurant facilities are often explored by Economics and Sociology. Socio-geographic studies of restaurant business have been mainly related to the devlopment of theories of spatial planning in social and commercial geography 
and urban planning aspects. At the present stage of the study restaurant facilities may be associated with Consumption Geography (fashion, mass consumption, and healthy lifestyle), Gender Geography, Urban Design and new courses, for example Agri-tecture - "a phenomenon involving the collaboration between agriculture and architecture, with aim to increase the self-production of organic and healthy food for the tenants of private allotments and the community within the city" (Bernardi, Bosio 2012) etc.

This article refers to P. Atkins (Atkins, Bowler 2001), A. Bosio, E. Bernardi (Bernardi, Bosio 2012), D. Sloan (Sloan, Leith 2004), C. Steel (Steel 2008), V. Karsekin (Karsekin 1990), G. Pyatnytska (Pyatnytska 2007), V. Doroshenko (Doroshenko 2005), who considered territorial and regional aspects of food production and restaurant facilities development in their studies. The latest integrated scientific paper related to restaurant facilities of Ukraine including Kyiv is a Pyatnytska 2007.

In this research philosophical methods, general scientific methods (classification, induction, deduction, literature review), and geographical research methods (correlation analysis, cluster analysis, survey, mapping, field research method) has been used. Following methods has been chosen to refer to the statistics database, field of exploring as an object of Human Geography and its specific features.

Analysis of literature demonstrates a background of the study.

Survey method has been used to collect data and analyze the behaviour of customers and its differences according to age, gender and the level of income. The questionnaire for respondents, included closed and open questions, has been conducted online and offline anonymously in 2015 in Kyiv city. The represented group consist of 199 respondents in the age between 17-45. Statistical error with a 0.95 confidence probability is $1,4 \%$.

Correlation analysis has been used to demonstrate connections between data variables. Data that tends to determine changes in other fields has been defined. Correlation analysis has been performed in "Statistica" program. Visual demonstration of data in graphs, piechart and trend lines graphs has been created for this paper.

Cluster analysis for restaurant facilities expresses actual regional differences, which based on integrated analysis of dissimilar data. Cluster analysis as one of the algorithms for the classification of statistical data performs a gradual combination of disparate elements into a single "tree". In this case, the geometric distances in the multidimensional space have been calculated through the Euclidean distance. The calculations used the method of full connection (the method of the most remote neighbours). In this method, the distances between clusters are determined by the greatest distance between any two objects in different clusters.

Mapping of restaurant facilities is a tool for visualization of regional differences. In this research, this is an integrity object. Maps for the paper have been created using GIS mapping method based on statistical data (Mezentsev 2004). Using 
maps of restaurant facilities is necessary for both - the individual consumer and for integrated geographic research in the field. Cartographic materials of this study have been carried out in the GIS-programs: MapInfo and Surfer, to demonstrate allocation and regional differences of the Kyiv region restaurant facilities.

\section{Results}

According to the State Standards of Ukraine, restaurant facilities are a type of economic activity aimed to satisfy consumer needs in nutrition with an arrangement of entertainment or without it (State Standards of Ukraine 2004).

In 2014 there were 20.6 thousand of entrepreneurs in restaurant business in Ukraine officially. The number of individual entrepreneurs according to various estimates is about three times bigger. Since 2014, the State Statistics Service does not provide data on number of establishments in restaurant business. The share of restaurant business in Ukrainian GDP is about $0.8 \%$ of nominal GDP. The share of employment in the hotel and restaurant business in Ukraine is about $1.8 \%$, or 357.8 thousand people. Ukrainians spent on services of hotels and restaurants only $1.1 \%$ of their income in 2002; in 2013, this indicator had risen to $2.5 \%$ (State Statistics Service of Ukraine 2015).

In European Union restaurant business is a part of hospitality sector, which also includes hotels. The potential market of jobs in the hotel and restaurant business in the EU is 16.6 million directly employed persons and around 6.4 million people connected with these fields. Restaurant business is an important place for youth employment, often as a first job. Reviews determined that the hospitality sector in the EU gives $3.7 \%$ of GDP (460 billion euros), $8.1 \%$ of production ( 1 trillion euros), provides employment for $7.8 \%$ population or every thirteenth workplace.

Hospitality sector gives the largest contribution to GDP in such countries as Cyprus, Greece, Malta, Portugal, Spain, Croatia, Austria (about 5-10\%), the largest share of employment is in Cyprus, Malta, Luxembourg (15-30\%). Relatively low figures of hospitality sector shared in GDP (1-2.5\%) are in Lithuania, Poland, Latvia, Denmark, Luxembourg, Norway, Romania, Slovakia, the share of employment (5\%) in Finland, Lithuania, Poland, Romania, Slovakia, Turkey (Lhermitte 2009; HOTREC 2013).

Food in a variety of forms is manufacturing and selling by many branches of economy (agriculture, food industry, trade etc.). However, only in restaurant facilities the functions of production, sale and consumption of prepared meals combines in a single location (Pyatnytska 2007).

Author considers that restaurant facilities in economy are combined by raw and production links with the food industry, trade, agriculture, by infrastructure links - with transport, construction and financial sector, by consumer links with education, culture, recreation and tourism and health sector. 
The socio-geographical significance of restaurant business consists of the

\section{following aspects:}

- meaning of food and its importance as the primary natural human need provides stable demand in consumption of all types of food services including restaurant services;

- the restaurant industry is a sector that accumulates the cultural experience of generations, and thus is a carrier of food traditions of whole nations. This suggests the strategic development of the industry to create the image of the country, including development of tourist industry through introduction of national cuisine;

- restaurant business in the city allows to make a journey across the globe and to expand the knowledge about other nations through their culinary traditions, therefore, this is an alternative way of international tourism (Sloan, Leith 2004);

- the restaurant industry is one of the most profitable business, particularly private business, which performs a social activity - restaurants usually are the first workplaces for young people. The service sector in cities, and restaurant facilities particularly, were the force of private enterprises growth in a post-soviet term (Glazyschev 2008);

- restaurant industry influenced by globalization and becomes the platform for innovation - digital technologies, including mapping projects, electronic mechanisms of information exchange;

- restaurant business is an alternative urban public space. Kyiv provides a lot of parks, libraries and squares for its citizens, visitors. However, urban areas are usually open, with no tree shadow and delimits (Males 2011). During a crisis of post-soviet economic period, the state of city public spaces has become critical, while private restaurant establishments invested significant funds to attract the visitors. Thus, restaurants and cafes become places for meeting, and communication;

- restaurant facilities are actively involved in the transformation of postindustrial space of the city - in particular, Europe's largest street food festival in Kyiv is located at the Art Factory Platform, which turned the location from factory to art cluster;

- restaurant industry develops not only as an institution for the food production, but also as a place of ideas exchange, social activism and education (thematic lectures in cafes);

- the system of city food nutrition is associated with architecture and planning of housing. Medieval buildings had been planned in a way to minimize sharing flavours of food from the kitchen - with many floors and corridors. For instance, fashion image of mistress in the 60's of the XX century in the United States had led to the open, spacious kitchens, which transforms into dining areas. 
Restaurant industry in the metropolitan area assumes function of dining room space and replacing kitchen in urban high-rise buildings. It serves as a platform for social interaction, meetings and celebrations (Steel 2008).

Restaurant business in Kyiv region became similar to actual condition stage in the nineteenth century. Events of the Soviet era made the most prominent impact on restaurant facilities, transformed restaurant business into „public catering”.

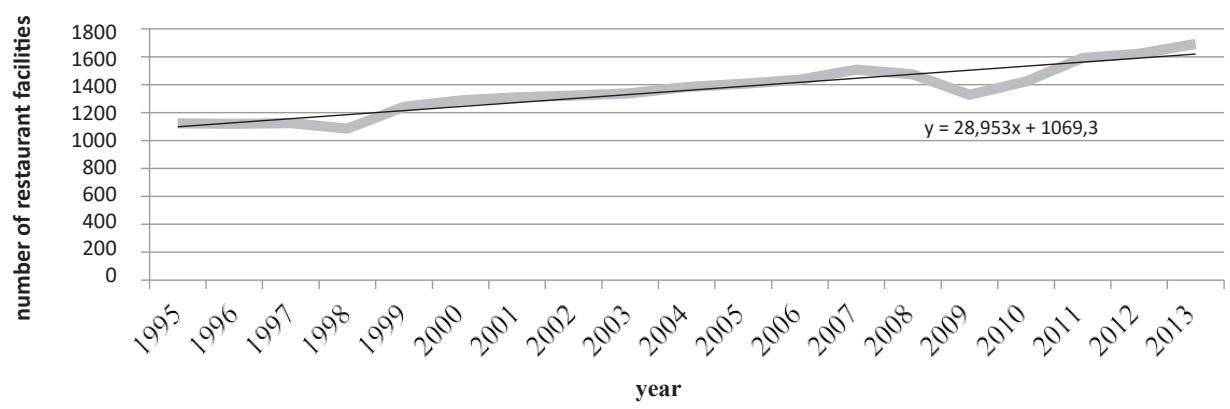

Fig. 1. Dynamics of the number of restaurant facilities, Kyiv, 1995-2013

Source: made by author based on State Statistics Service of Ukraine data (http://www.ukrstat.gov.ua/; http://www.kiev.ukrstat.gov.ua/)

Over the period of independence, Ukrainian restaurant business became an industry extremely sensitive and susceptible to economic and political events. City formation, including Kyiv, affected by the processes of globalization primarily, accelerates the exchange of information and changing consumer trends. Quantity of enterprises increases and highly depends on the general economic situation in the country.

Public opinion is one of the best indicators of human problems and concerns. In this study, it has been decided to use quantitative social survey for the analysis of Kyiv region restaurant industry.

Analysis of the debrief demonstrates that answers the question ,What is your main purpose for attending restaurant?" can be divided in the following way: $42 \%$ respondents visit restaurants and cafés for daily meeting with friends and dating, $41 \%$ - for nutrition, $11 \%$ - for entertainment and getting a new experience, $5 \%$ - for celebrations, and $1 \%$ use it as a workplace. Thus, restaurant facilities change their function from place to eat to place for communication (Fig. 2).

Regarding the territorial organization of restaurant facilities respondents claim:

- "in dormitory district, it is necessary to develop a network of cafes, to improve menu, to vary concept, diversify cheap establishments with conceptual cafe with rational pricing to attract locals";

- "there is an insufficient presence of enterprises and their diversity in the peripheral areas of the city"; 


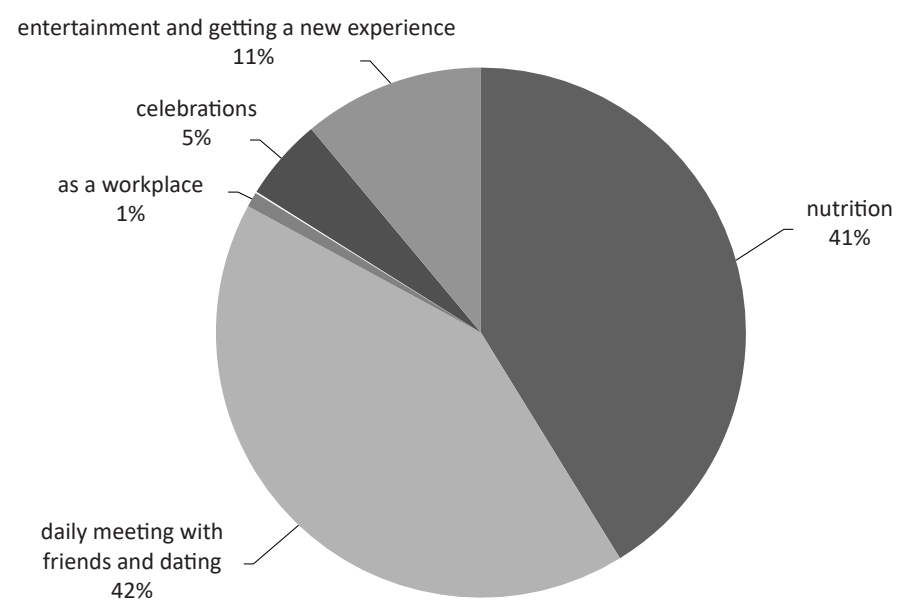

Fig. 2. Results of the survey about the Kyiv region restaurant facilities, 2015

Source: based on author's research

- "there is too high concentration of restaurant facilities in the city centre";

- "there is no equal price/quality ratio of the restaurant facilities outside Kyiv city".

For analysis of interrelationships of the key indicators of restaurant business (the number of establishments and the retail trade turnover) with other factors of the restaurant industry development through correlation analysis has been implemented. Particularly, the correlation analysis in "Statistica" programme determines a significant relationship. The types of connections are both direct and inverse (Fig. 3).

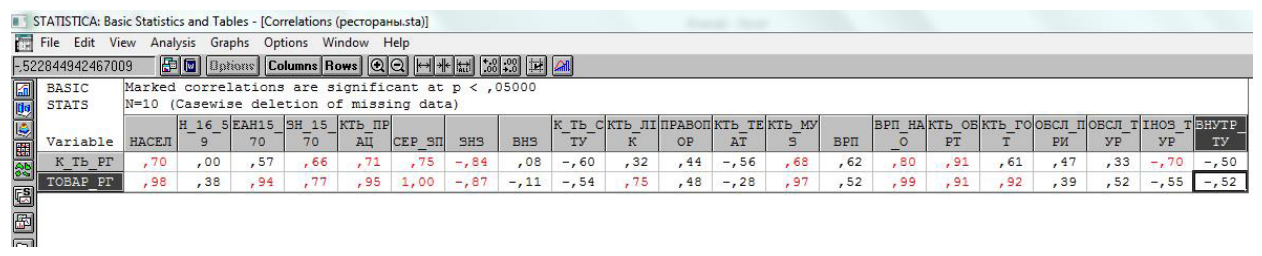

Fig. 3. Results of the correlation analysis of key indicators of restaurant business, Kyiv city, 2004-2014

Source: made by author based on State Statistics Service of Ukraine data (http://www.ukrstat.gov.ua/)

Thus, the number of establishments of restaurant facilities depends on:

- number of retailers - correlation rate is 0.91 ;

- GRP per capita - 0.8;

- the average salary of employees -0.75 ; 
- number of employees -0.71 ;

- number of population -0.7 ;

- number of employed persons aged 15-70 years -0.66 ;

- number of museums - 0.68 .

An inverse connection had been exposed with the following indicators:

- number of secondary schools -0.84 ;

- number of foreign tourists -0.7 .

Retail turnover directly correlated with:

- the average salary of employees - correlation rate is 1 ;

- GRP per capita - 0.99;

- population -0.98 ;

- employees - 0.95;

- number of economically active population aged $15-70$ years -0.94 ;

- number of retailers -0.91 ;

- number of employed persons aged $15-70$ years -0.77 ;

- number of museums - 0.97;

- number of hotels -0.92 ;

- number of hospitals -0.75 .

Inverse connection had been exposed with following indicator:

- number of secondary schools --0.87 .

The analysis reveals that the influence of infrastructure figures (hotels, schools etc.), population figures (number of tourists, students etc.) are less important than figures of economics and infrastructure (wages, GRP, the number of trade).

Fig. 4 demonstrates the statistical surface of number of Kyiv restaurant facilities. A number of restaurants in the city centre is characterized by peak shape which rapidly attenuates and accomplishes the minimum rates at the periphery. Such distribution is explained by the concentration of business, tourism and educational activities in the city centre, which tends to increase the restaurant facilities activity.

Implementation of cluster analysis based on official statistics for the year 2013, allows to identify five clusters of Kyiv districts and surrounding areas of Kyiv region. The number of enterprises of restaurant business, the number of seats in enterprises and the volume of retail turnover has been analyzed (Fig. 5).

Results of conducted research allows to observe following regional differences of restaurant facilities: the core of Kyiv region is clearly formed by Shevchenkivsky and Pechersky districts (Kyiv downtown), decrease of the restaurant activity is marked to the periphery of the city. Country restaurant enterprises have an obvious localization along the highway directions (form Kyiv to Zhytomyr, Odesa, Obukhiv, Brovary, Boryspil) and water recreation facilities (along the Dnipro river, which crosses the city from north to south, and Vyshgorodskiy lake - on the north of Kyiv) - Fig. 6. 


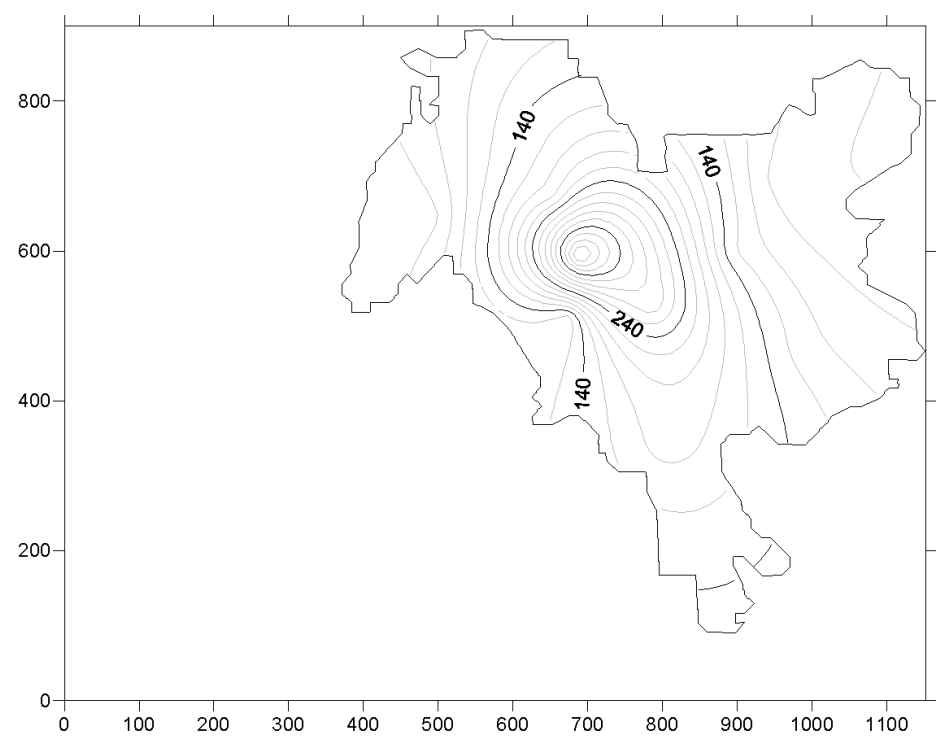

Fig. 4. Statistical surface of number of Kyiv restaurant facilities, 2016

Source: made by author based on Database of restaurants of Kyiv region "Doroga" (http://www.doroga.ua/restaurants/Kievskaya/1057); Database of Kyiv restaraunts "Lasoon" (http://lasoon.com.ua/)

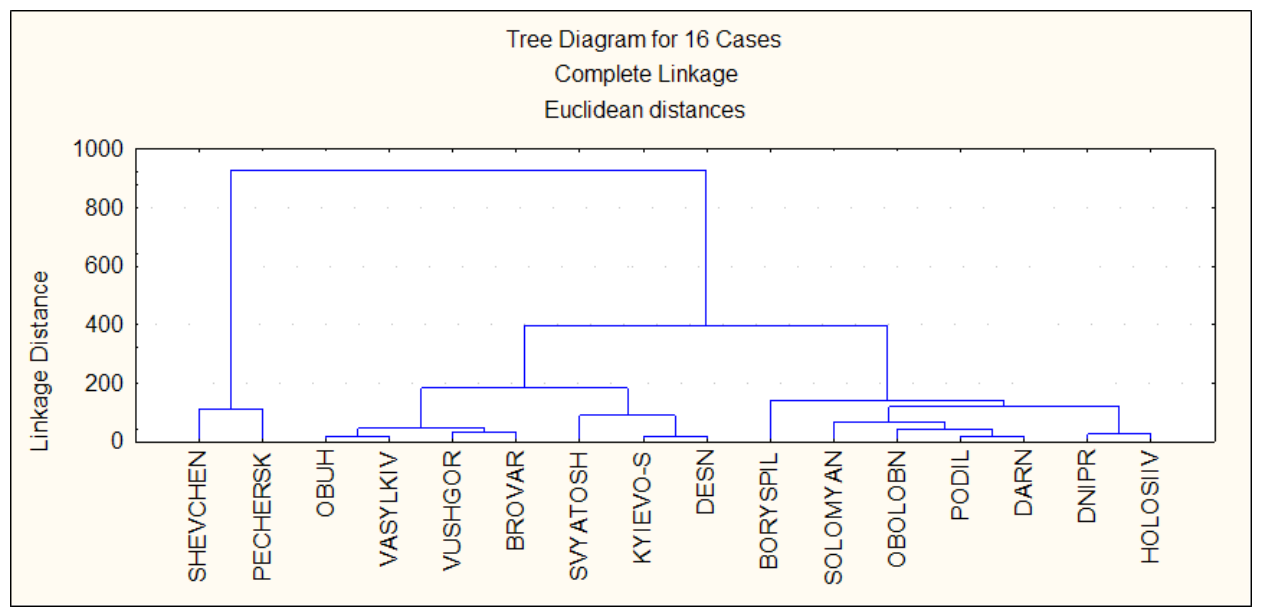

Fig. 5. Tree of clustering of restaurant facilities of Kyiv region, 2013

Source: made by author based on State Statistics Service of Ukraine data (http://www.ukrstat.gov.ua/) 


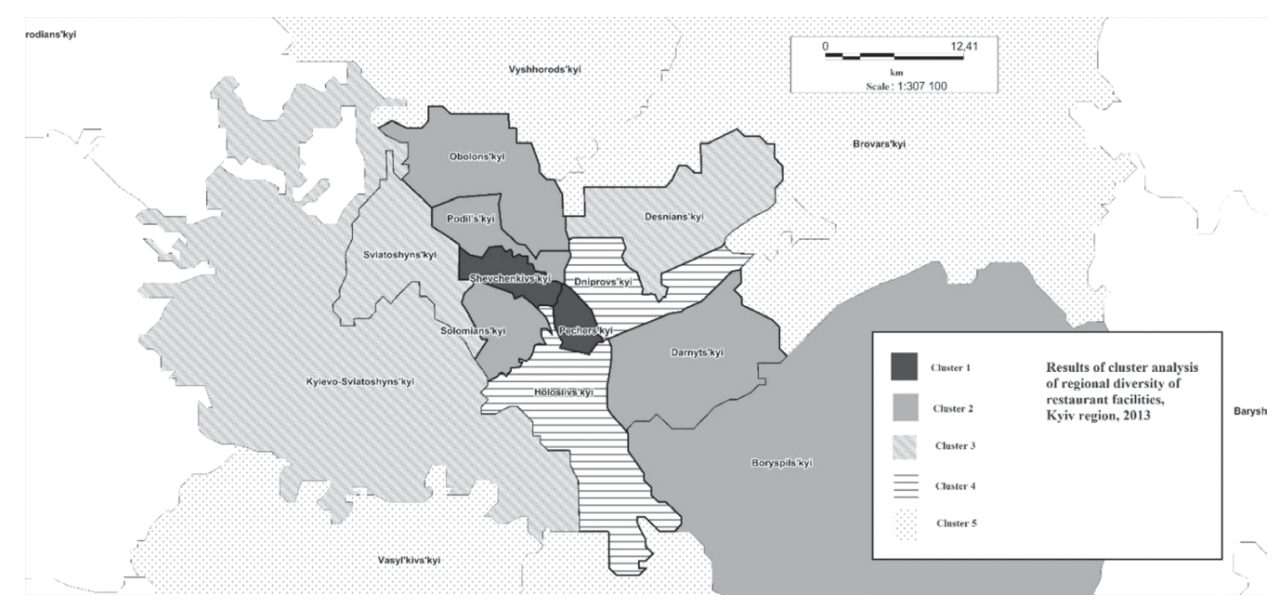

Fig. 6. Map of clustering of the Kyiv region districts by restaurant facilities indicators, 2013

Source: made by author based on State Statistics Service of Ukraine data (http://www.ukrstat.gov.ua/; http://www.kiev.ukrstat.gov.ua/; http://oblstat.kiev.ukrstat.gov.ua/)

In the city centre the functions of node elements of restaurant concentration are fulfilled by shopping centers.

Centre elements can be treated as institutions coupled by consumer activity - public spaces (parks, squares, recreation areas, office areas, tourist centres etc). They do not have an explicit form, but rather form of merged linear or radial concentration of restaurant facilities.

Point elements are essentially formed by every single object of restaurant industry (this vision based on the functional and territorial structure of regional items (Doroshenko 2005).

The author believes that the main tasks for the territorial organization of restaurant facilities improvement of Kyiv region are:

- to create the territorial structure of restaurant facilities which could response to the needs of the area residents;

- to ensure the functioning of restaurant facilities in the socially important sectors (education, medicine);

- to regulate the interaction of restaurant business with urban space (placement of small seasonal booth, summer terraces etc.).

\section{Conclusions}

Research investigation demonstrates the uneven distribution of restaurant facilities in the Kyiv region. The current state of allocation and excessive concentration of restaurant facilities in central areas of Kyiv city is a natural consequence of 
the architectural layout of the city and the complexities of its development. The compact placement of cultural and historical city centre, hotels, entertainment, shops and the largest scientific and educational institutions in the centre of capital, leads to assembling enterprises and causes the mess in usage of public space.

The possibility to reverse this trend and to reduce the burden in the central city area is considered only through the downtown planning change. Some restaurants, mainly elite suburban enterprises, are localized in the city recreational area and in the surrounding suburban areas, which provides convenient transport accessibility (near main highways). Author assumes that the demand for those services will be stable and there is no reason for changing their placement.

Restaurant facilities sector is an important part of the economy, a type of urban public space and the way of international cultural cooperation. Calculation presents that restaurant facilities and their territorial structure heavily depends on economic conditions. Thus, restaurant facilities form an integral part of the urban complex, and their territorial organization depends on the features and functions of the territory.

It is useful to provide extending researches to explore changes during a certain period, to examine ways of international cultural interaction through restaurant services in the specific region and to study which part of the food services in the big city restaurant facilities could cover the demand.

\section{LITERATURE}

Alonzo R., 1995, Upstart Guide Owning \& Managing a Restaurant, Kaplan Business, New York: $1-225$.

Atkins P., Bowler I., 2001, Food in society: economy, culture, geography, Arnold, London: 1-11.

Berezhnoi I., 1980, Development of public catering in Ukraine, Vyscha Shkola, Kyiv: 1-215. Bernardi E., Bosio A., 2012, Un-dissociating architecture and agriculture: urban food and agri-tecture, Ravensbourne, http://www.academia.edu/11131069/Un-dissociating_architecture_and_agriculture_Urban_food_and_agri-tecture (accessed on: 05.09.2016).

Database of Kyiv region "Doroga", http://www.doroga.ua/restaurants/Kievskaya/1057 (accessed on: 05.09.2016).

Database of Kyiv restaraunts "Lasoon", http://lasoon.com.ua/ (accessed on: 05.09.2016).

Doroshenko V., 2005, Geography of internal trade, Kyiv University Publishing Center, Kyiv: $1-19$.

Dudnyk I., 2002, Territorial organization of services, Asmi, Poltava: 1-100.

Glazyschev V., 2008, Urban studies. Part 1, Europe, Moscow: 11-14.

Godsmark C., 2005, How to start and run your own restaurant, How To Content, A division of How To Books Ltd., Oxford: 1-247.

HOTREC (European trade association of hotels, restaurants and cafes - Hotrec), http:// www.hotrec.eu/ (accessed on: 05.09.2016).

Karsekin V., 1990, Regional problems of public catering development, Vyscha Shkola, Kyiv: $1-27$. 
Kuznetsova N., 1997, Basics of economics of hotel and restaurant facilities, University of Tourism, Kyiv: 1-173.

Lawson F., 1994, Restaurant planning and design, Van Nostrand Reinhold, New York: $1-335$.

Lhermitte M., 2009, Reinventing European growth, Ernst \& Young's European attractiveness survey, http://www.eyeim.com/pdf/Attractivite\%202009\%20Web.pdf (accessed on: 05.09.2016).

Males L., 2011, Centrality and publicity. Strategies of Kyiv Urban Future: a collection of public discussions, articles, interviews and projects, Alfa-Print, Kyiv: 28-35.

Marvin B., 1991, Restaurant Basics: Why Guests Don't Come Back and What You Can Do About It, Wiley, New York: 1-240.

Mezentsev K., 2004, Regional forecasting of social and economic development: A manual, Kyiv University Publishing and Printing Center, Kyiv: 12-20.

National Restaurant Association, 2015, Facts at a Glance, http:/www.restaurant.org/ News-Research/Research/Facts-at-a-Glance (accessed on: 02.05.2016).

Otsuka M., 2015, Food Service Hotel Restaurant Institutional. Japan HRI Food Service Sector Report 2014, USDA Foreign Agricultural Service, GAIN Report Number: JA 4519, Washington, 1-40.

Pyatnytska G., 2007, Restaurant business of Ukraine: market transformation, innovative development, structural shift: monograph, KNTEU, Kyiv: 1-44.

Sloan D., Leith P., 2004, Culinary taste: consumer behavior in the international restaurant sector, Elsevier Butterworth Heinemann, Oxford: 44-56.

State Standards of Ukraine 4281: 2004, Restaurant facilities. Classification, http://document.ua/zakladi-restorannogo-gospodarstva-klasifikacija-nor2728.html (accessed on: 05.09.2016).

State Statistics Service of Ukraine, http:/www.ukrstat.gov.ua/ (accessed on: 02.05.2016).

State Statistics Service of Ukraine, Kyiv City Department, http:/www.kiev.ukrstat.gov.ua/ (accessed on: 02.05.2016).

State Statistics Service of Ukraine, Kyiv Region Department, http://oblstat.kiev.ukrstat. gov.ua/ (accessed on: 02.05.2016).

Steel C., 2008, Hungry City: How Food Shapes Our Lives, Random House, London: 228-255. Usov V., 1990, Organization of services in restaurants, Vysshaya Shkola, Moscow: 1-208. Walker J., 2008, Restaurant from concept to operation, John Wiley \& Sons, Inc., Hoboken: $1-493$.

Yurkivskyi V., 1989, Geography of services sphere, Ukrvuzpoligraf, Kyiv: 1-81.

\section{USLUGI GASTRONOMICZNE: ORGANIZACJA PRZESTRZENNA I MIEJSCE W GEOGRAFII CZLOWIEKA (PRZYKLAD OBWODU KIJOWSKIEGO)}

Zarys treści Prezentowany artykuł ma na celu opisanie najważniejszych cech sektora usług restauracyjnych i jego organizacji terytorialnej w okręgu kijowskim. Gastronomia może być postrzegana jako część ekonomiki, która w ciągu ostatnich dziesięcioleci notuje dynamiczny rozwój, przyczyniając się do wzrostu gospodarczego i zapewniając miejsca pracy. Stanowi 
także istotną część infrastruktury turystycznej i przestrzeni publicznej, ułatwia komunikację międzyludzką i stanowi interesujące zjawisko kulturowe, które rozpowszechnia wiedzę i różne tradycje żywieniowe na całym świecie.

W regionie kijowskim procesy rozwoju gastronomii można zaobserwować we wszystkich rodzajach lokali konsumpcyjnych - w kawiarniach, barach, usługach kateringowych, restauracjach, punktach typu fast food, w sferze dostaw itp. W pracy podkreślono znaczenie obiektów restauracyjnych w gospodarce. Przeprowadzono analizę danych statystycznych i osobistą obserwację przestrzennej organizacji obiektów restauracyjnych w Kijowie i przyległych terenach. Dokonano również analizy korelacji powiązań przemysłu restauracyjnego i analizę klastrów w celu określenia różnic regionalnych.

Przeprowadzone badania prowadzą do określenia stanu rozwoju obiektów gastronomicznych z perspektywy geografii człowieka i prezentują najnowsze trendy w rozwoju tej dziedziny gospodarki. Ponadto zidentyfikowano problemy i sposoby poprawy branży restauracyjnej w Kijowie, a także zaproponowano kilka zaleceń dotyczących dalszych badań.

Słowa kluczowe Usługi gastronomiczne, organizacja przestrzenna, rozwój miasta, Kijów.

Kateryna Dmytriieva, MSc Department of Economic and Social Geography Faculty of Geography Taras Shevchenko National University of Kyiv e-mail:k.dmytriieva@gmail.com 